\title{
A Study of Entrepreneurship Substitute to Job Market in the Context of Bangladesh
}

\author{
Nargis Sultana \\ Assistant Professor \\ Department of Finance \& Banking, Comilla University, Bangladesh
}

\begin{abstract}
Immense competition in job market, competitive exam patterns in getting a job, nepotism etc. all are making a job very tough for an unemployed youth nowadays. Even after getting a job, they find lack of independence, job stress, sub ordinance, tiring working hours, politics too severe to tolerate. Entrepreneurship is the act of creating a business either from the scratch or from already an established one ensuring independence, freedom, decision making power, flexible work hours etc. The study will cover all the problems associated with getting and sustaining in the jobs. Besides, all the positive impacts of entrepreneurship will be included in a broad aspect as it has multi-dimensional activities to perform. The obstacles to facilitate entrepreneurship will also be covered so that future corrective actions can be taken to. On top of that, a comparison will be made between these two to represent an evaluation. The role of regulatory authority will also be focused whereas the attention of mass people will be drawn at length. This study will be beneficial as it will come up with potentiality of a particular sector which will remove the problem of unemployment to a great extent and play a role in the economy of our country.
\end{abstract}

Keywords:Job Market, Nepotism, Job Stress, Entrepreneurship, Decision Making Power, Regulatory Authority, Unemployment.

DOI: $10.7176 / \mathrm{EJBM} / 13-13-02$

Publication date:July $31^{\text {st }} 2021$

\subsection{INTRODUCTION}

Entrepreneurship is becoming more popular these days, as many people are becoming interested in gaining freedom from their employment. Rather than working for a company, they are branching out into becoming entrepreneurs and becoming their own boss. As this trend is growing at a fast rate. In spite of the financial security a job offers, there are often situations when people are willing to give it all up. Frustration with the boss, no career improvement prospects, not liking the job or simply growing tired of doing the same old thing may lead someone to consider beginning his own venture. On the basis of the entrepreneurship and job's factors, entrepreneurship may be an alternative to the job market in Bangladesh. The country has experienced rapid economic growth, structural shifts in the economy, increase in educational attainment levels, and rapid urbanization since gaining its independence in 1971. Empirical evidences showed that, productive employment plays a key role in transmitting the benefits of economic growth into poverty reduction. But still, Bangladesh is not to the way of full employment level. Job market is highly competitive here. The number of job seekers and also the job satisfaction level of the employed are not at desired level. Besides, as a labor abundant country, the prospect of the entire economy of Bangladesh depends on the features of the labor market. The changing features of the composition of labor force, employment, unemployment scenario depends on various factors such as demography, structural change, change of social attitude. In Bangladesh, labor force participation is growing at a faster pace than the current employment generating capacity of the economy making it difficult for the country to absorb the incremental labor force in productive and remunerative employment. The current unemployment rate in Bangladesh is 4.2 and the employed person is 60 million that labor force participation increasing in a steady way, female participation on labor force are increasing rapidly, labor participation on others sectors are more than agricultural sector. Labor are migrating rural to urban due to industrialization and development of infrastructure. As such, the country needs higher and more employment intensive economic growth.

\subsection{METHODOLOGY OF THE STUDY}

\subsection{Collection of Data}

Data has been collected from both primary and secondary sources. List of closed or multiple choice questions have been distributed to a sample of 200 people (online, in person and over the phone). The primary data was collected on the basis of questionnaire prepared in the light of the objective of the study.

\subsection{Sample Size}

The survey was conducted among the unemployed youth seeking jobs, employed youth in various sectors and entrepreneurs in Bangladesh. A total of 200 samples was gathered. The purpose and premises of the questionnaire was explained to the selected respondents assuring of total confidentiality of the data. 


\subsection{OBJECTIVES OF THE STUDY}

- To evaluate the opinion of the entrepreneurs, job seekers \& job-holders about their present situation in competitive market and preference for entrepreneurship.

- To explore the current scenario of job market which demotivates the youth.

- To identify the factors leading to the increasing popularity of entrepreneurship.

\subsection{LITERATURE REVIEW}

It's ill-starred, however, to mark that the economics of supply and demand in regards to employment aren't identical. According to a study of Bangladesh Bureau of Statistics (BBS), as many as 400,000 youths with university degrees are now unemployed. This has left around 4.37 percent (BBS) of the total labor workforce, wandering from one place to another looking for work. This gigantic unexploited human capital can be transformed to assets by stimulating entrepreneurship and inclusive ventures. Entrepreneurship development is becoming increasingly important because it creates a lot of impression on the locality and changes the lives of the people. Earlier, businesses were all about profit but now enterprises are working towards becoming inclusive, where they care about people, planet and profit.

Entrepreneurship is a influential factor of economic development (Thurik, 2009; Hessels and van Stel, 2011; Audretsch et al., 2015), social and structural change (Acs et al., 1999; North, 2005). Entrepreneurship not only contributes to the economic and social growth of a nation, but also stimulates the development of knowledge (Shane, 2000), technological change (Acs and Varga, 2005), competitiveness and innovation (Parker, 2009; Blanco-González et al., 2015). Entrepreneurial activity is not just about discovering new ideas and possibilities (Shane and Venkataraman, 2000), but also intentional planning, developed through the cognitive processing of internal and external factors (Del Giudice et al., 2014). Intention is a cognitive process that precedes the effective involvement of the individual in any type of activity (Liñán and Chen, 2009), and in particular, entrepreneurial intention is closely linked to business world (Moriano et al., 2012) and has become a rapidly evolving research sector in the international scene (Liñán and Fayolle, 2015).

Currently, in the literature there are two different theoretical approaches which attempt to clarify why some individuals are more inclined toward an entrepreneurial career when compared to others: the first analyzes personality traits (Zhao and Seibert, 2006; Rauch and Frese, 2007; Leutner et al., 2014; DeNisi, 2015), the second focuses on environmental and behavioral factors (Peterson, 1980; Aldrich, 1990; Baum et al., 2001). Specifically, researchers study the importance of some individual traits as factors predetermining to perform entrepreneurial activities such as high levels of self-efficacy (Krueger et al., 2000; Zhao et al., 2005; Lee et al., 2011; Rasul et al., 2017), risk propensity (Schwartz and Whistler, 2009; Tumasjan and Braun, 2012; Yurtkoru et al., 2014), tolerance to ambiguity, and uncertainty (Hmieleski and Corbett, 2006; Schwartz and Whistler, 2009; Arrighetti et al., 2012), metacognitive abilities and individual abilities (Kor et al., 2007; Dickson et al., 2008; Liñán et al., 2011), locus of control (Battistelli, 2001; Gordini, 2013), as well as creativity (Hamidi et al., 2008; Smith et al., 2016; Biraglia and Kadile, 2017); the environmental and behavioral focuses refers to the Social Learning Theory (Bandura, 1986), according to which, individuals learn certain skills from other people, which act as models. Specifically, the term "role model" emphasizes the individual's tendency to identify with other people occupying important social and the consequent cognitive interdependence of skills and behavior patterns (Gibson, 2004).

Stam and vanstel (2009) used two scales of measuring entrepreneurship: The rate of entrepreneurship based on necessity and opportunity. Results indicated that the effect of these scales depends on the level of development in these countries. Koo and Kim (2009) established a model of economic growth. The rate of economic growth is the function of the growth rate of economically useful local knowledge function of R\&D, university research, social capital, entrepreneurship, human capital and the industry's structure. They found that entrepreneurship has a significant role in regional growth. Jonathan T. Eckhardt , Scott A. Shane (2003) explains the importance of examining entrepreneurship through a disequilibrium framework that focuses on the characteristics and existence of entrepreneurial opportunities.

There has been to extensive research on the potentiality of entrepreneurship as an alternative to the job market considering the challenges and future prospects. The study aims at determining those factors which make entrepreneurship worthwhile.

\subsection{PROSPECTS OF ENTREPRENEURSHIP IN BANGLADESH}

In the entrepreneurship scene of our country, challenges vary from entrepreneurs to entrepreneurs following some criteria. Each and every aspiring entrepreneur faces a different dilemma from their side. So, it becomes difficult to judge and come to a conclusion stipulating the particular prospects. Our country is spilling over with numerous unemployed people with potentiality in the periphery. With a growing economy, having an increasing youth population, entrepreneurs will be a key driving force to meet the needs of the industry and economy. A statement, published in a national English daily, has stated, in a research report carried out among 1,270 young 
people in Bangladesh who have at least one university degree, more than $42 \%$ participants reported the lack of fund as the major reason for not being able to start a venture. In our country's perspective, no doubt, funding is the greatest challenge for entrepreneurs rather than in other developed countries, although funding seldom determines the success of a venture according to various successful entrepreneurs. There are so far 7 Million small entrepreneurs in the country. It sounds good to learn a massive amount of participation in entrepreneurship seemingly but the amount frustrates with the world ranking of entrepreneurship where of Bangladesh places itself in the 133rd position in Global Entrepreneurship index 2017 among 137 countries. The survey which shows Bangladesh at the lowest place among all countries in Asia according to Global Entrepreneurship Week (GEW) is extremely disheartening for us. One of the core problems behind this lower ranking can be the funding obstacle. The present entrepreneurial ecosystem is gradually getting momentum in Bangladesh.

Several national and international business incubation and acceleration programs have been endorsed which is praiseworthy. Innovation Hubs, Apps development contest, digital marketing trends and institutional focus on entrepreneurship have been contributing to upgrading the ecosystem. By certifying entrepreneurship development in Bangladesh we can ensure industrialization, capital formation, market formation, innovation, balancing wealth distribution with innovative product and services, Gross Domestic Product (GDP) growth, balance inflation, the balance of trade increasing living standard and certainly maximum utilization of natural resources using technology. One of the important topics of the roundtable was many local giants are stepping into e-commerce in 2017. But the market needs more mature efforts. Some urged that the government is very interested and putting significant efforts to support the start-ups via developing hi-tech parks, idea, project, mobile gaming project and the community will see more fruit bearing actions very soon.

\subsection{ANALYSIS OF THE STUDY}

1. How is the current situation in the job market? Good or Bad?

Answer:

\begin{tabular}{ll}
\hline Good & $\mathbf{1 2} \%$ \\
\hline Bad & $88 \%$ \\
\hline
\end{tabular}
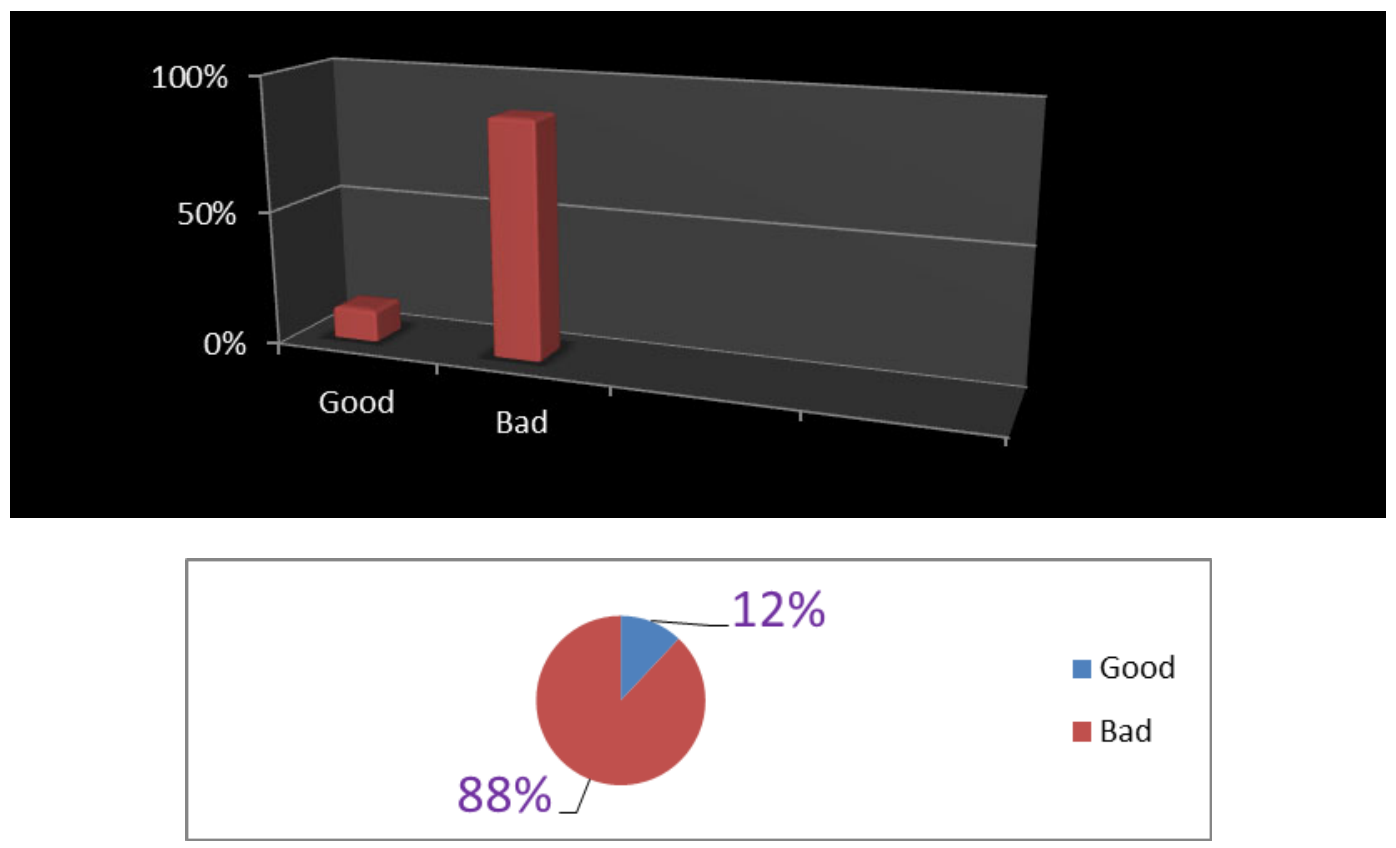
2. What do you want to do in BD context? Answer:

\begin{tabular}{ll}
\hline Entrepreneur & $\mathbf{5 2} \%$ \\
\hline Job & $48 \%$ \\
\hline
\end{tabular}

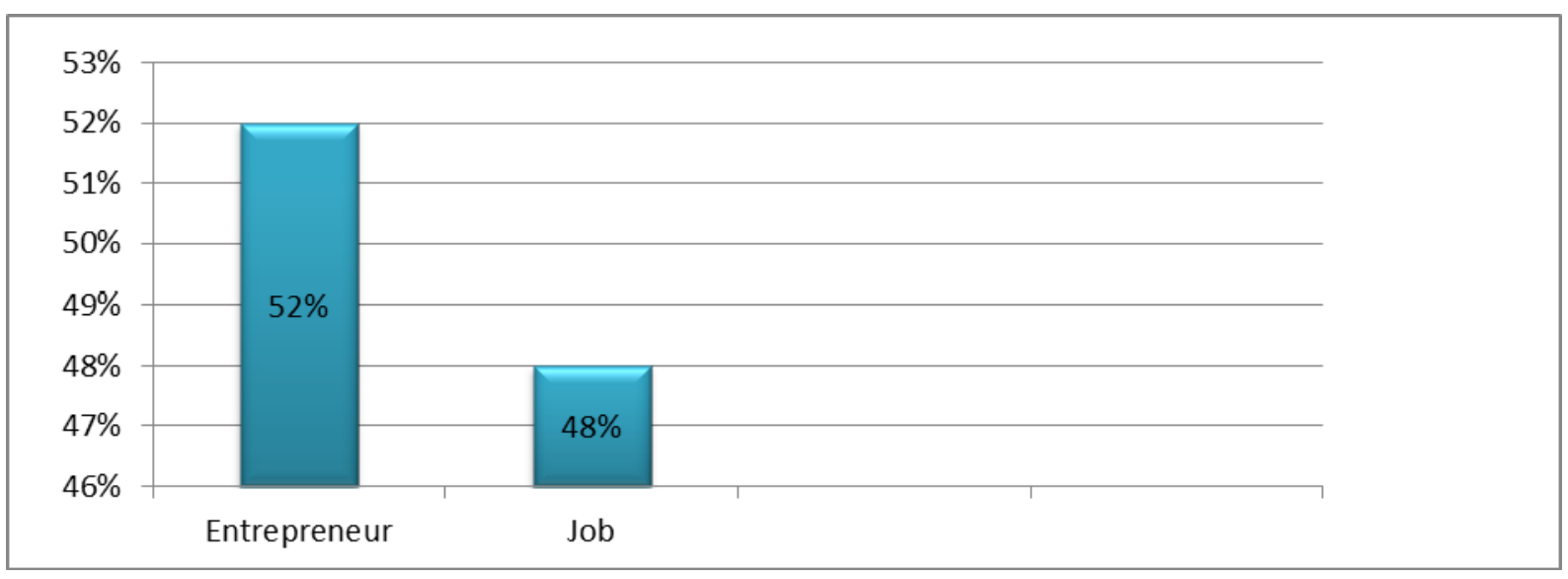

3. Which option is the most risky in your opinion?

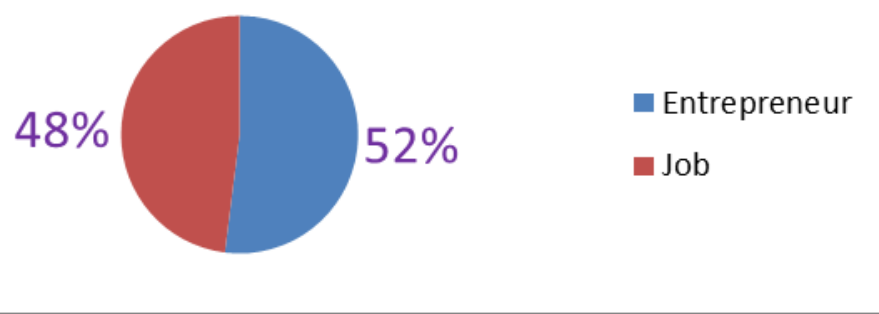

Answer:

\begin{tabular}{ll}
\hline Entrepreneur & $\mathbf{8 4 \%}$ \\
\hline Job & $16 \%$ \\
\hline
\end{tabular}
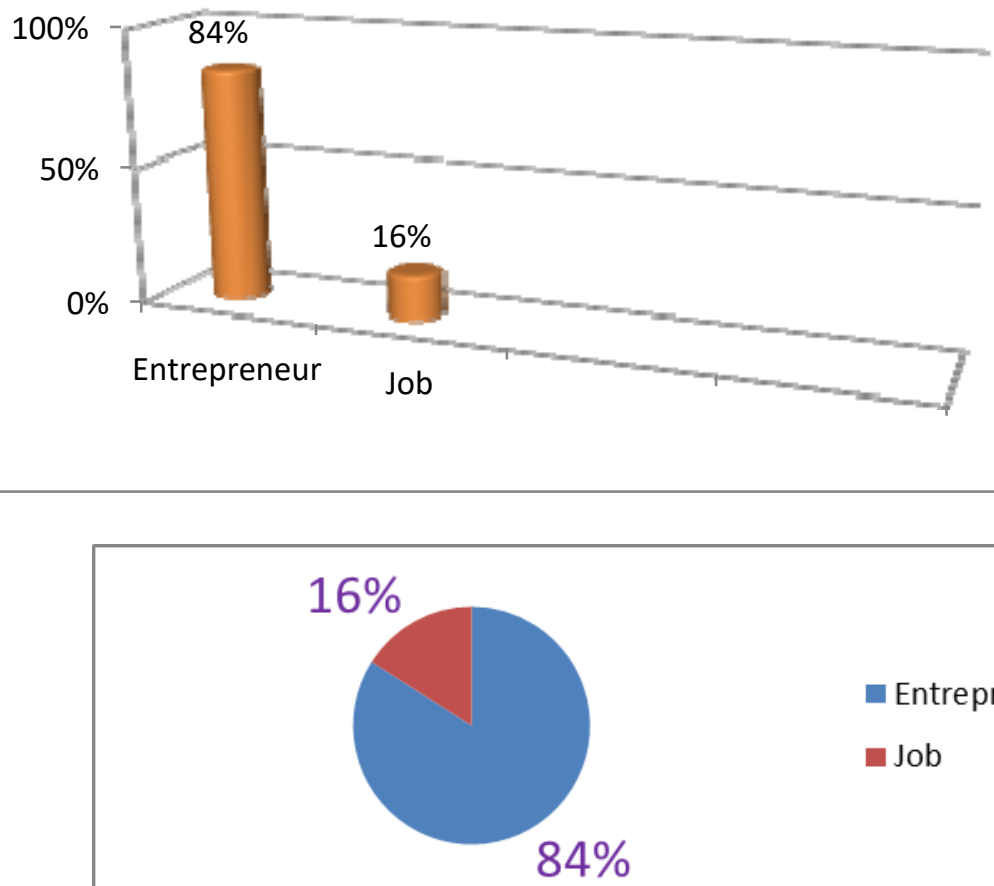

Entrepreneur

Job 
4. Which alternative offers more freedom?

Answer:

\begin{tabular}{ll}
\hline Entrepreneur & $\mathbf{9 6 \%}$ \\
\hline Job & $4 \%$ \\
\hline
\end{tabular}
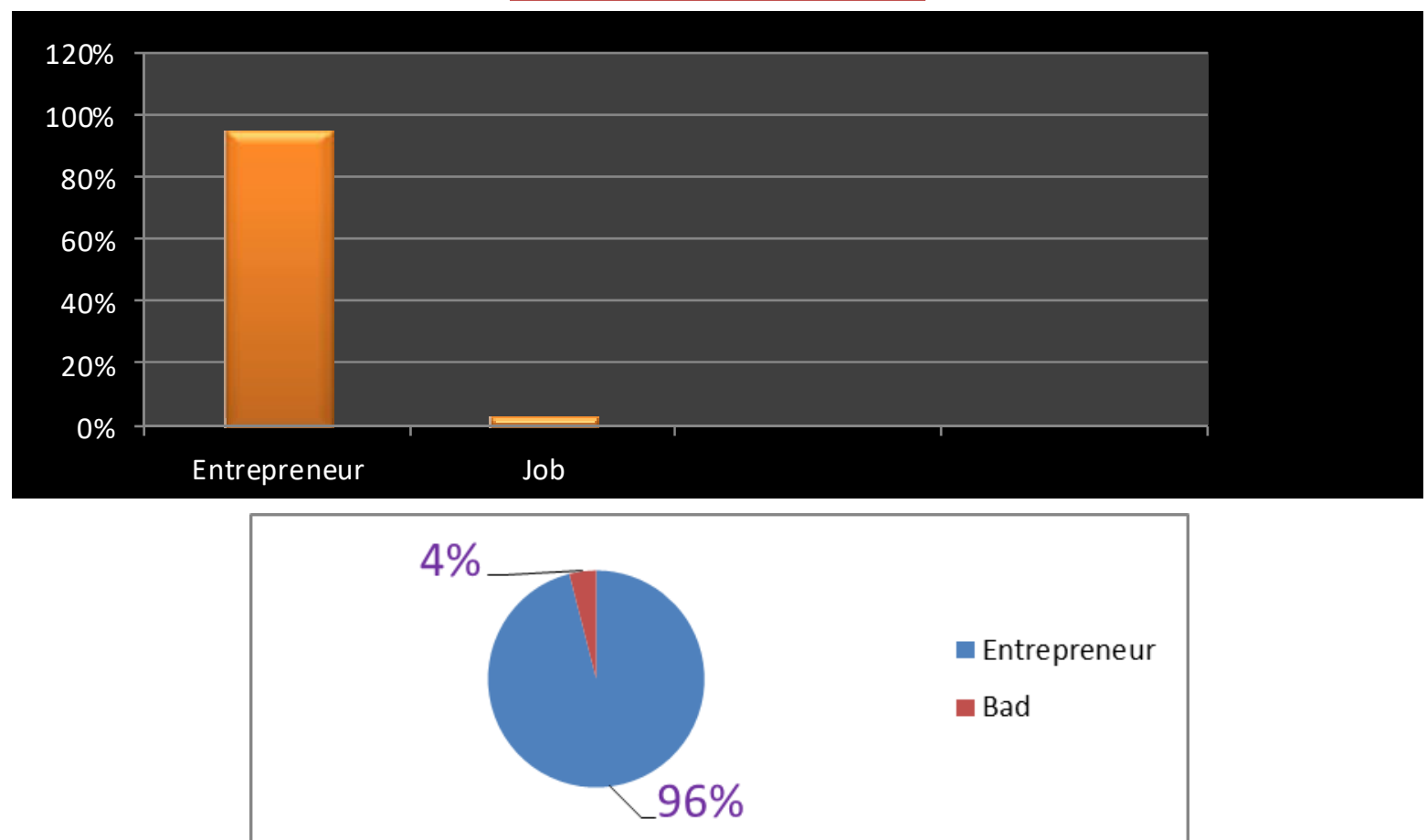

5 . What will you prefer to overcome poverty?

Answer:

\begin{tabular}{ll}
\hline Entrepreneur & $\mathbf{8 4 \%}$ \\
\hline Job & $16 \%$ \\
\hline
\end{tabular}
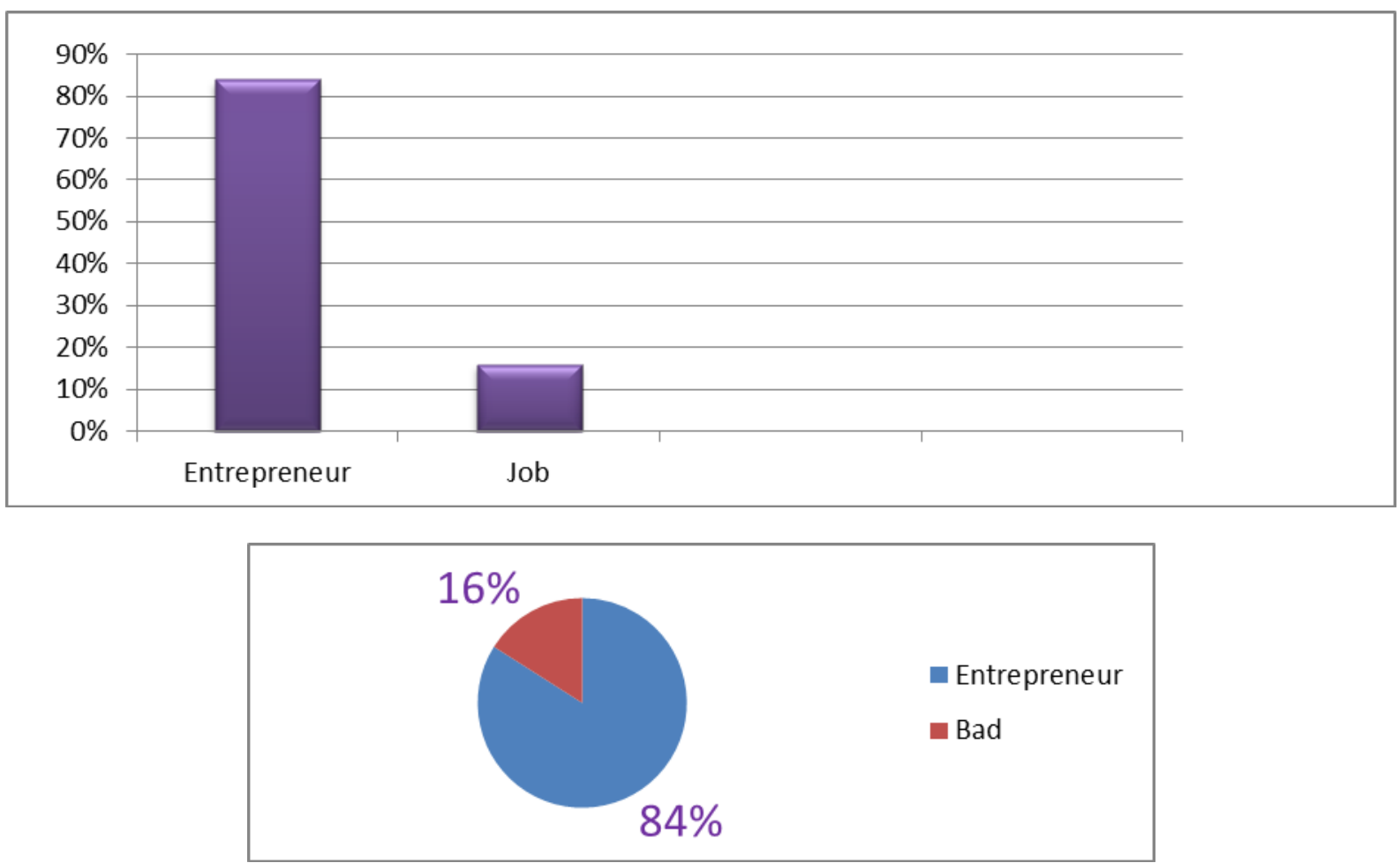
6. Which alternative plays the significant role of GDP growth in BD? Answer:

\begin{tabular}{ll}
\hline Entrepreneur & $\mathbf{9 2 \%}$ \\
\hline Job & $8 \%$ \\
\hline
\end{tabular}

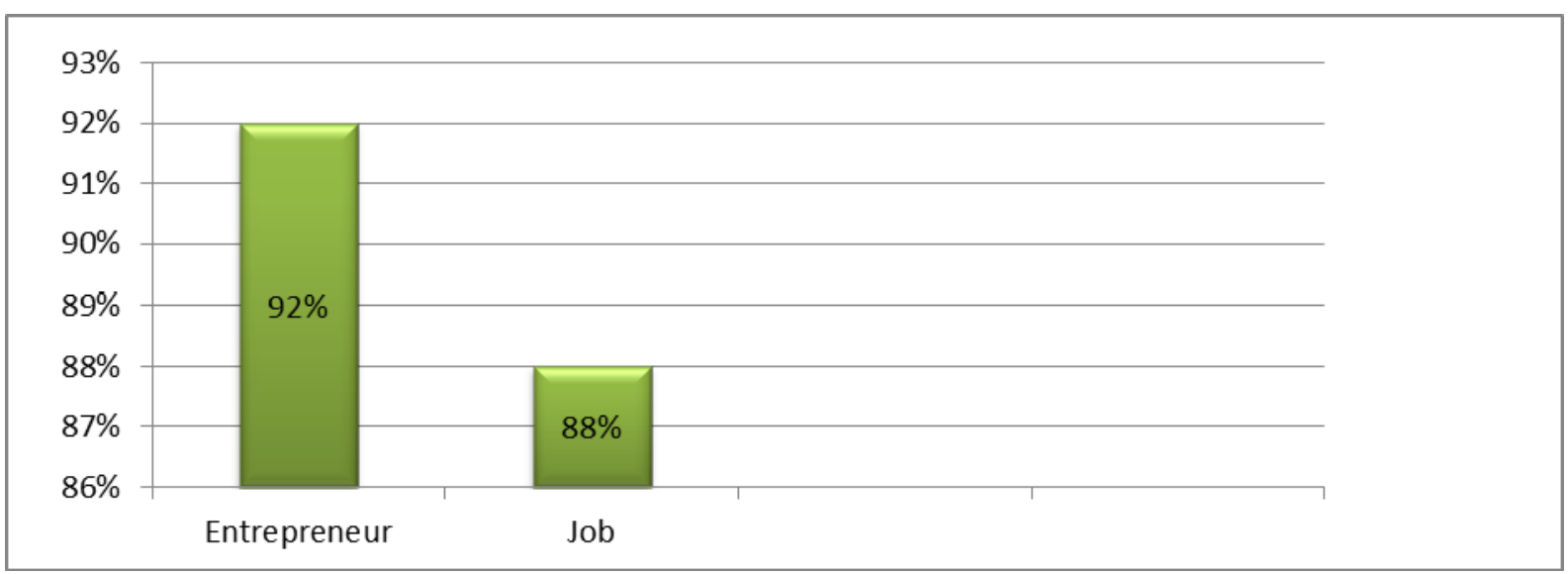

7. To be an entrepreneur if any education is needed?

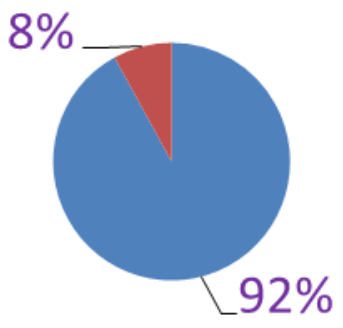

Entrepreneur

Job

Answer:

\begin{tabular}{ll}
\hline Yes & $\mathbf{9 4 \%}$ \\
\hline No & $6 \%$ \\
\hline
\end{tabular}

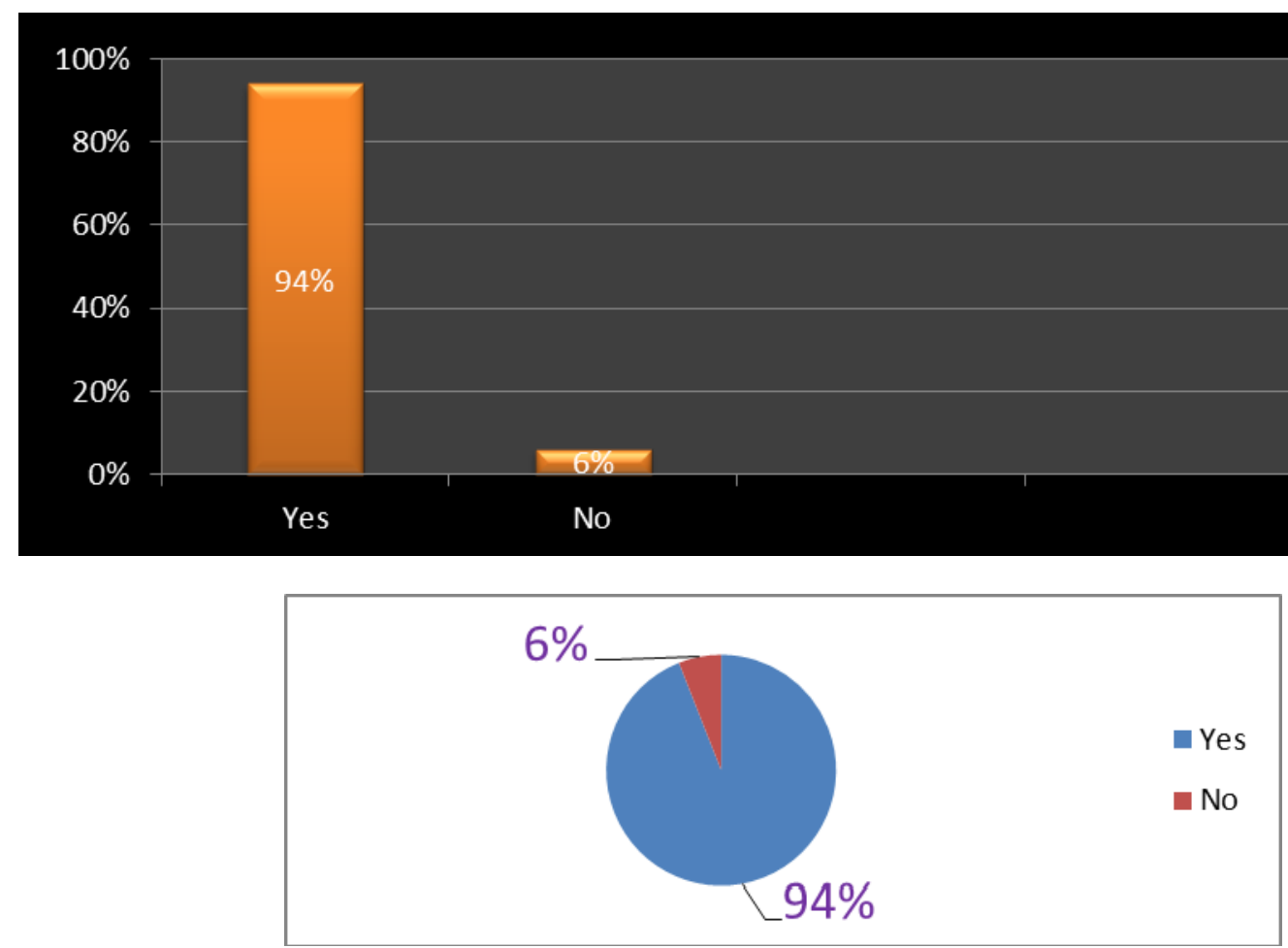


8. In your opinion if there is sufficient training in $\mathrm{BD}$, to be a successful entrepreneur? Answer:

\begin{tabular}{ll}
\hline Yes & $\mathbf{2 4 \%}$ \\
\hline No & $76 \%$ \\
\hline
\end{tabular}
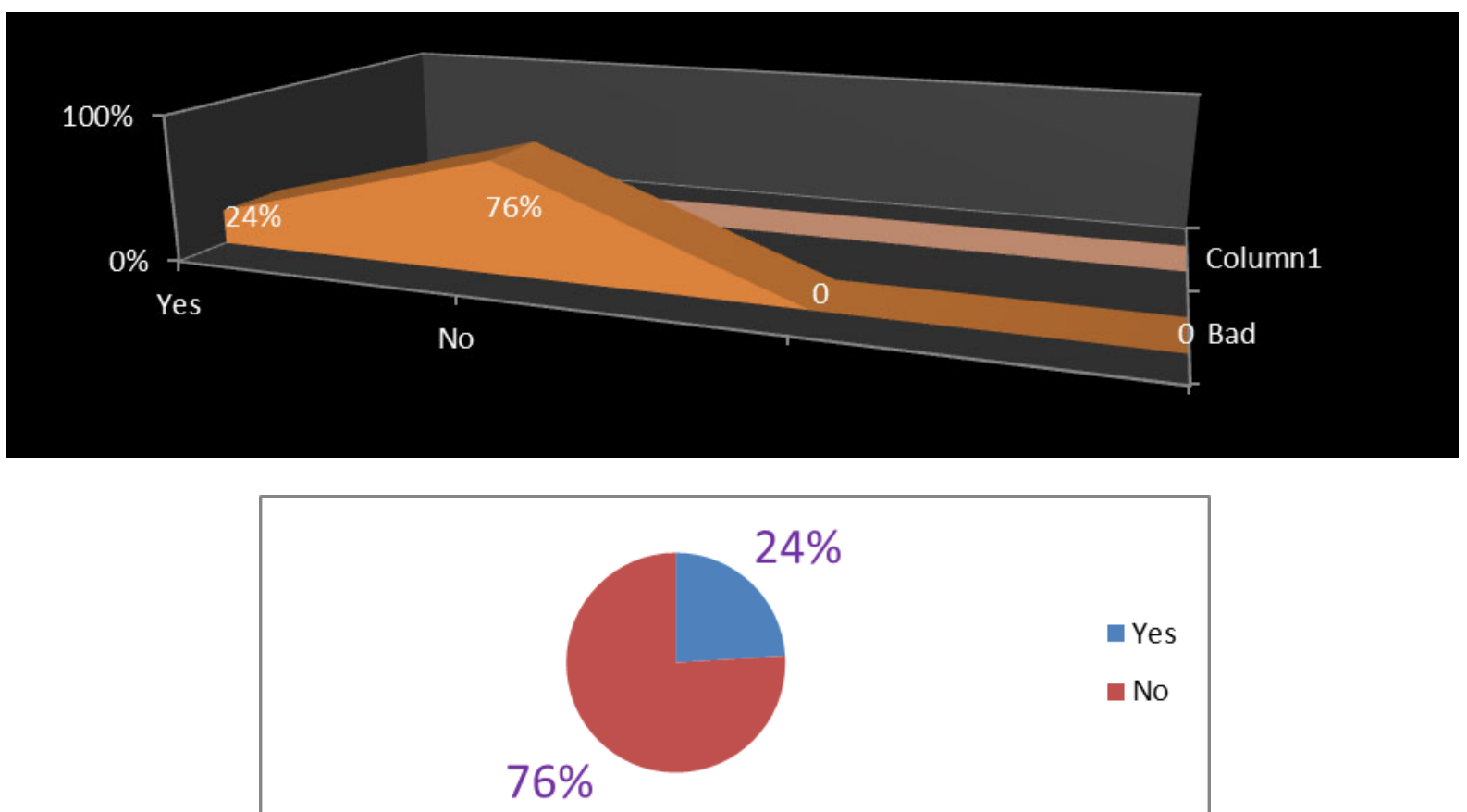

9. Whether are there sufficient loan arrangements for managing entrepreneur activities? Answer:

\begin{tabular}{ll}
\hline Yes & $\mathbf{4 2 \%}$ \\
\hline No & $58 \%$ \\
\hline
\end{tabular}
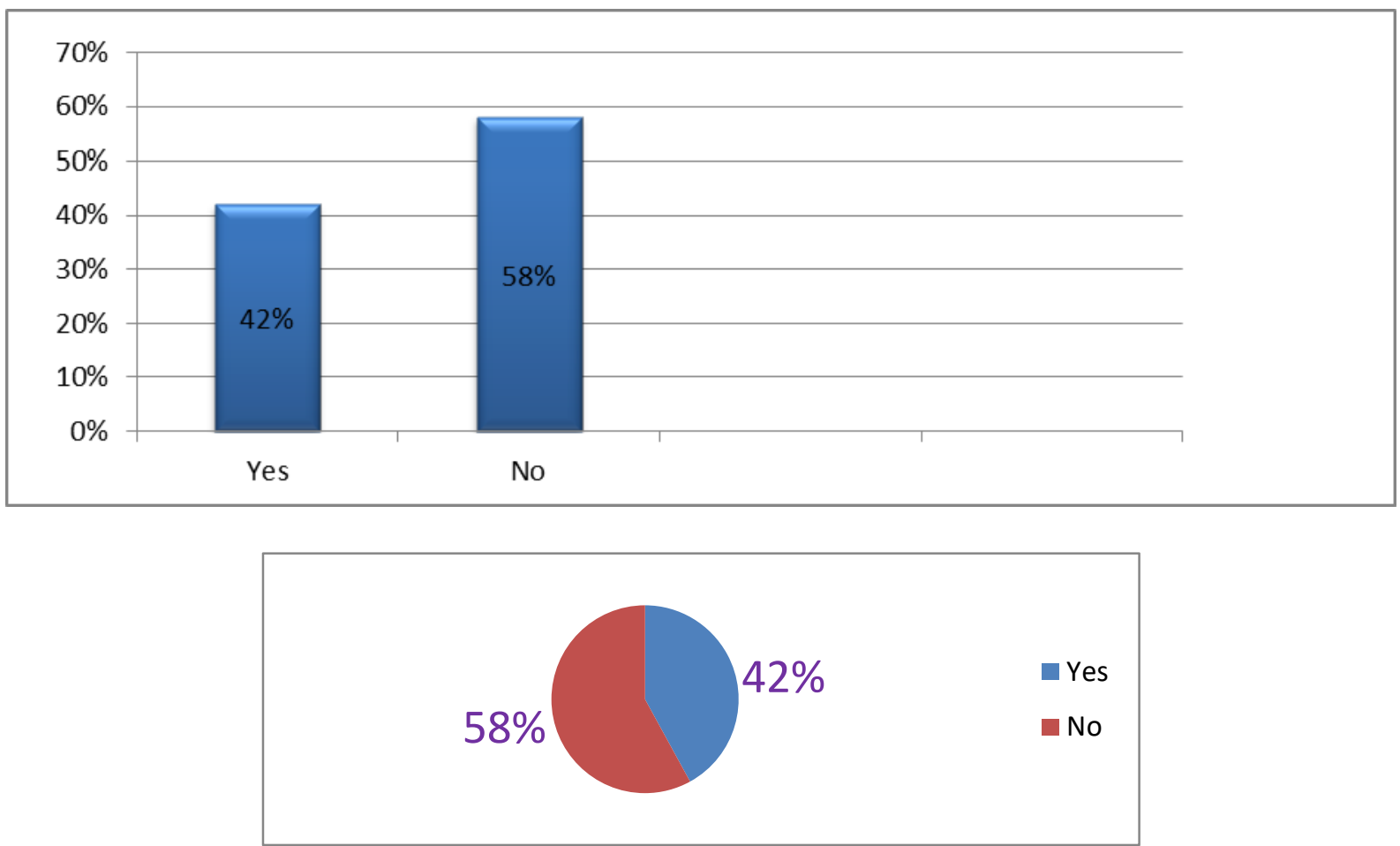
10. Which alternative's remuneration is the best?

Answer:

\begin{tabular}{ll}
\hline Entrepreneur & $\mathbf{6 4 \%}$ \\
\hline Job & $36 \%$ \\
\hline
\end{tabular}

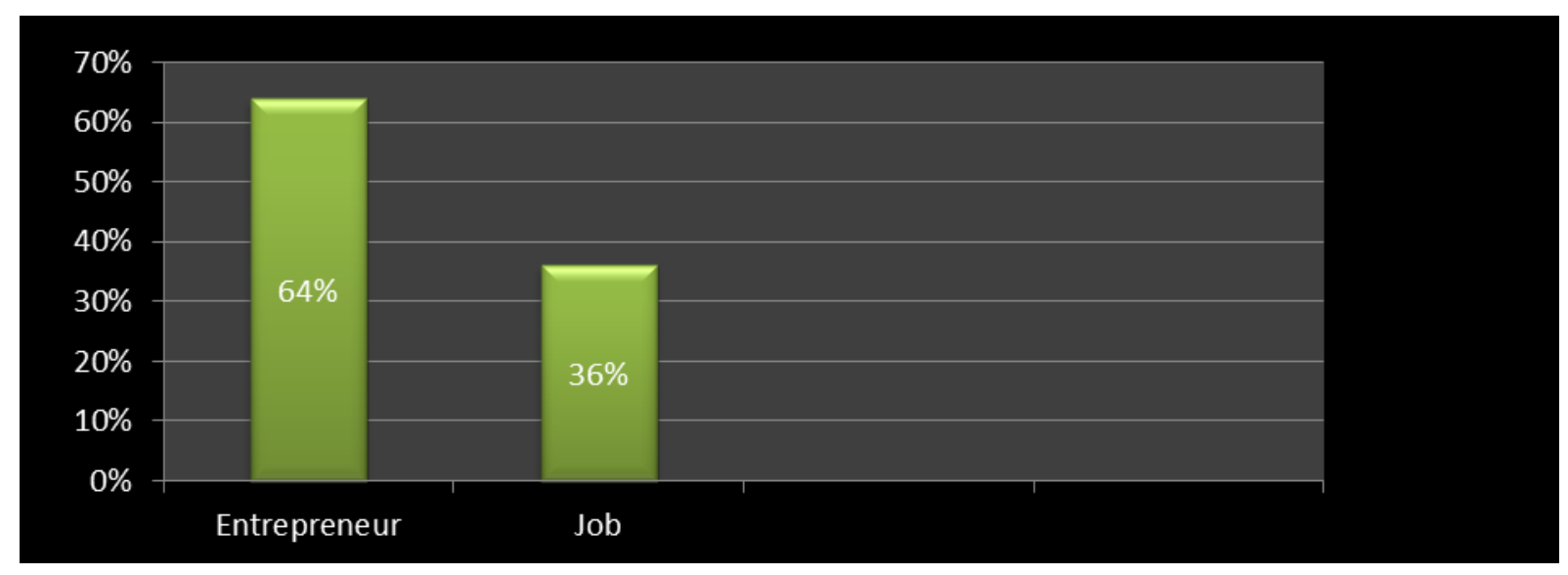

11. Who plays the role of socio-economic development?

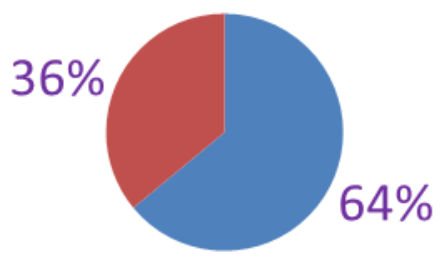

\section{Answer:}

\begin{tabular}{ll}
\hline Entrepreneur & $\mathbf{9 2} \%$ \\
\hline Job & $8 \%$ \\
\hline
\end{tabular}
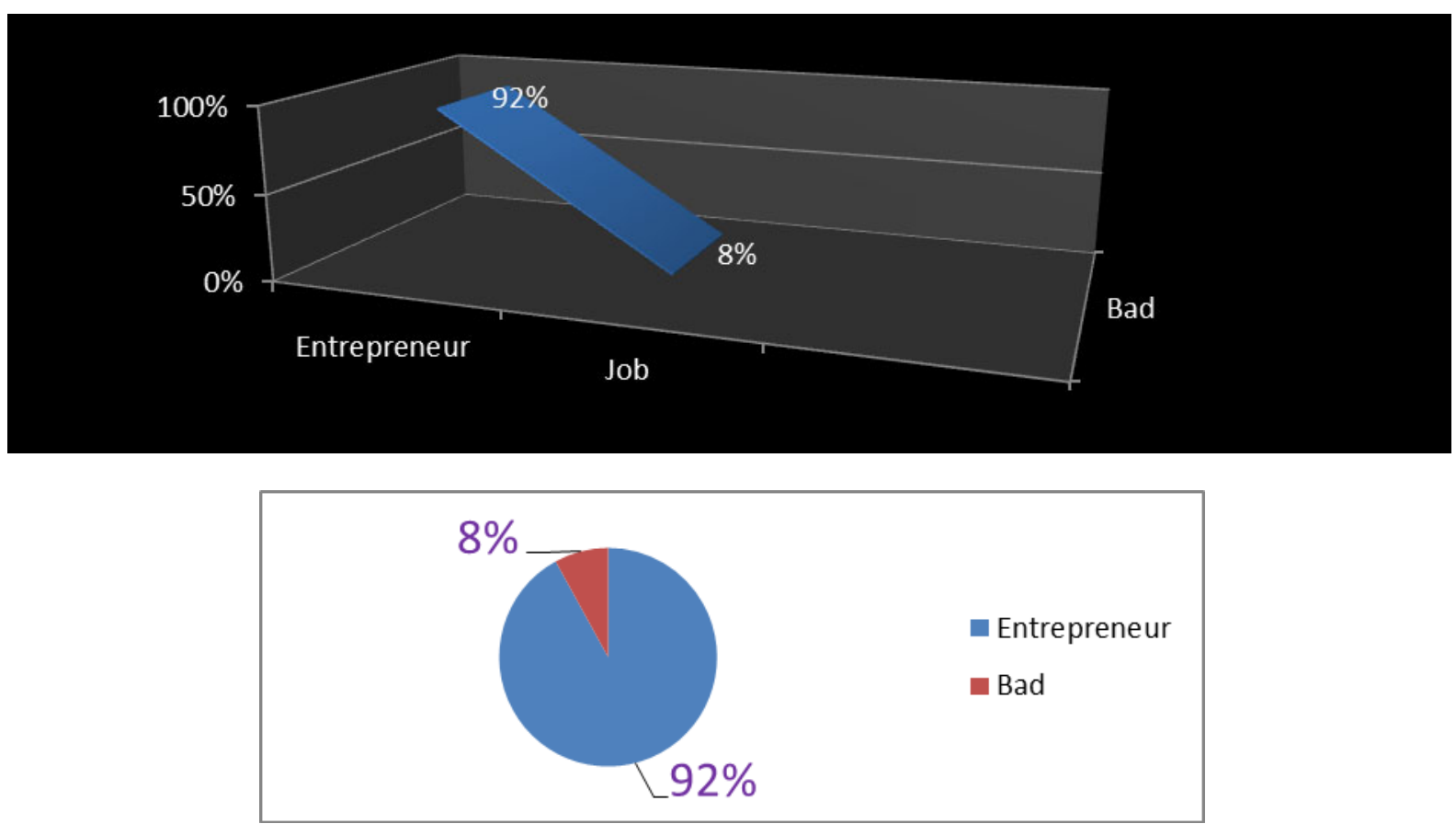
12. In the context of other developing countries in which sector BD is forward entrepreneurship or job? Answer:

\begin{tabular}{l|l}
\hline Entrepreneur & $\mathbf{5 4 \%}$ \\
\hline Job & $24 \%$ \\
\hline None of them & $22 \%$ \\
\hline
\end{tabular}
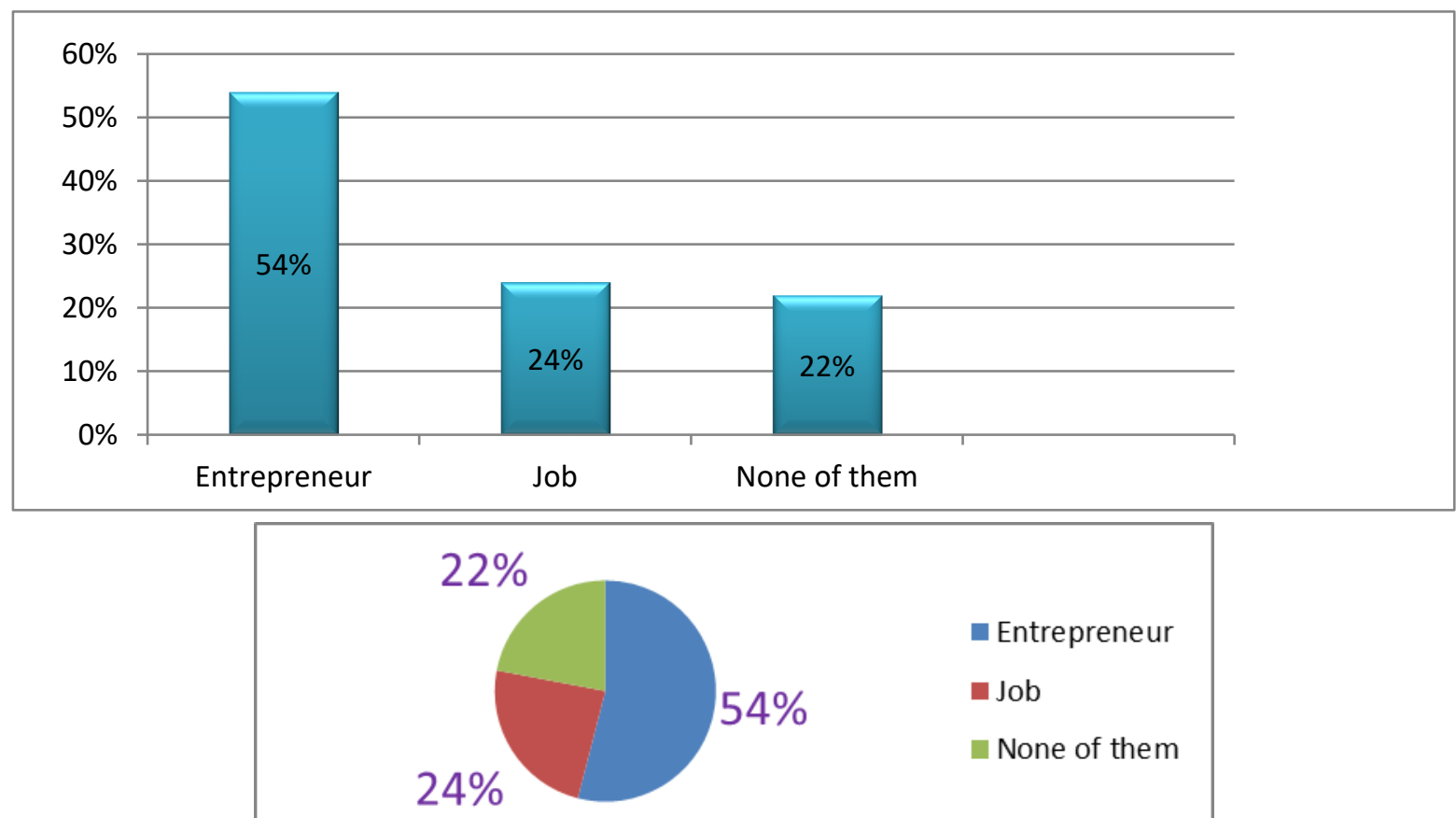

13. Does the government have a role to play is the development of the entrepreneurship as an alternative to job? Answer:

\begin{tabular}{ll}
\hline Yes & $\mathbf{4 6 \%}$ \\
\hline No & $54 \%$ \\
\hline
\end{tabular}
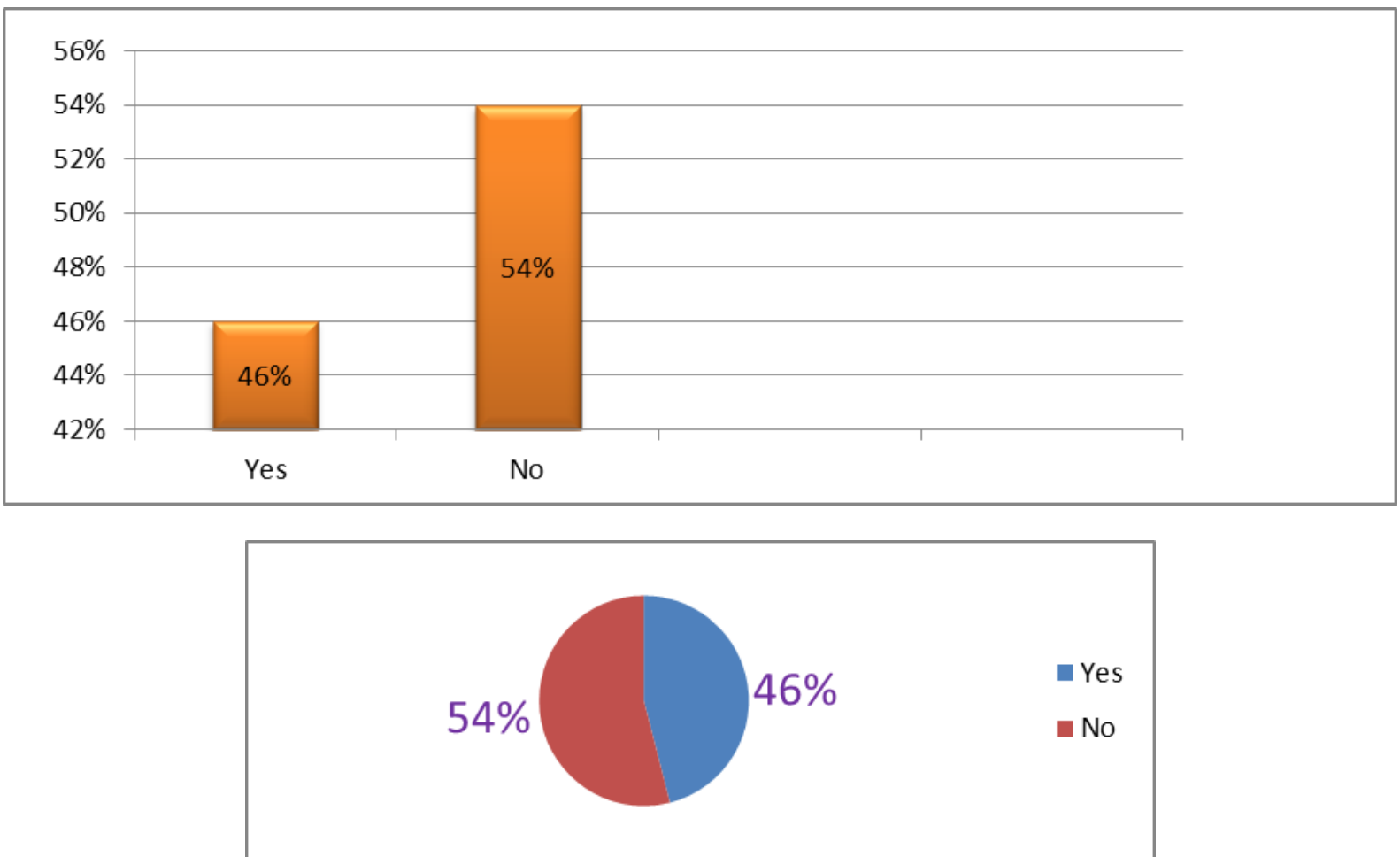
14. Which alternative is the role of $\mathrm{BD}$ in creating employment? Answer:

\begin{tabular}{ll}
\hline Entrepreneur & $\mathbf{8 8 \%}$ \\
\hline Job & $12 \%$ \\
\hline
\end{tabular}
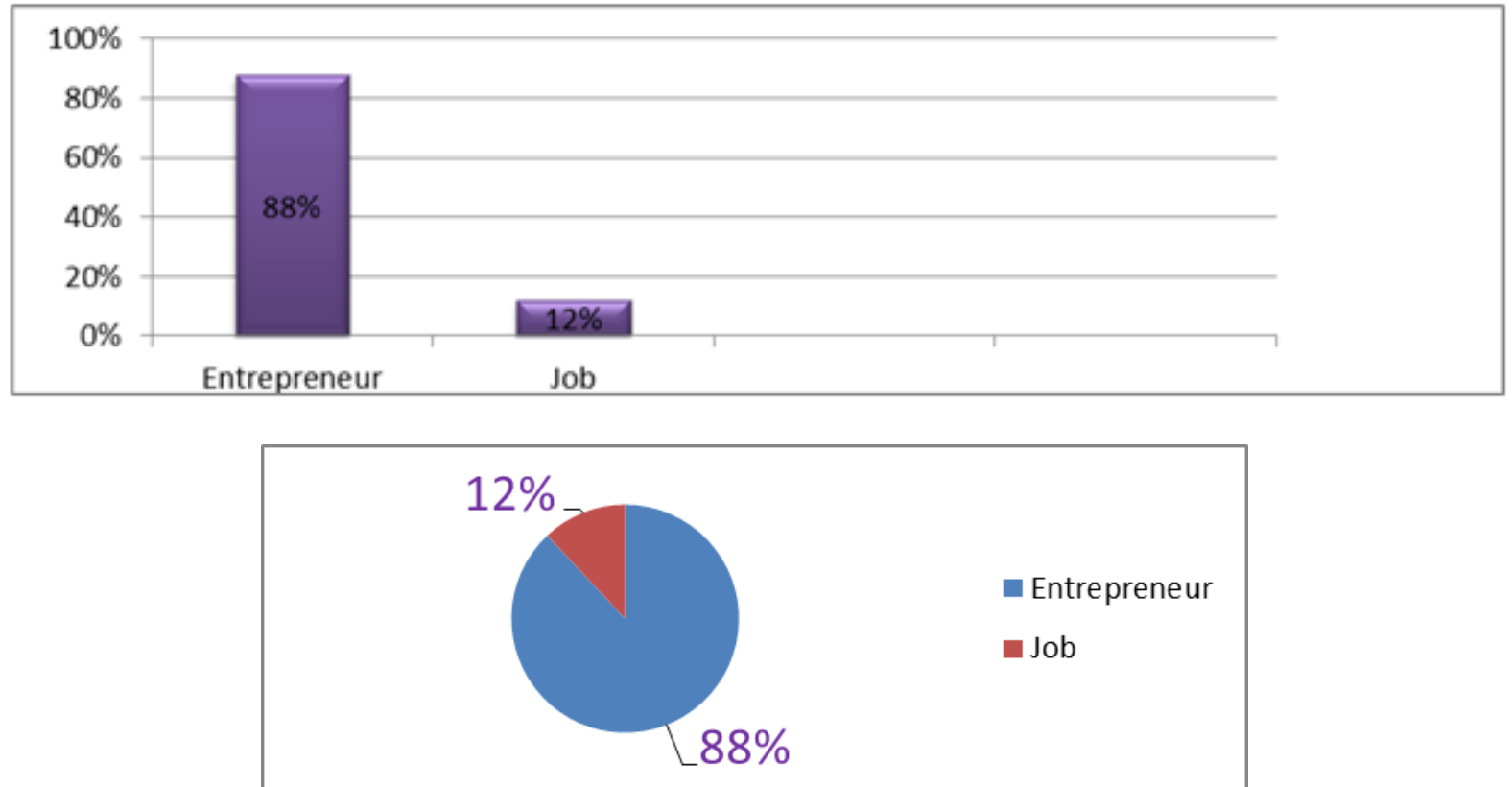

15 . Why don't you want to be an entrepreneur?

Answer:

\begin{tabular}{l|l}
\hline Money & $\mathbf{5 0} \%$ \\
\hline Courage & $10 \%$ \\
\hline All & $40 \%$ \\
\hline
\end{tabular}
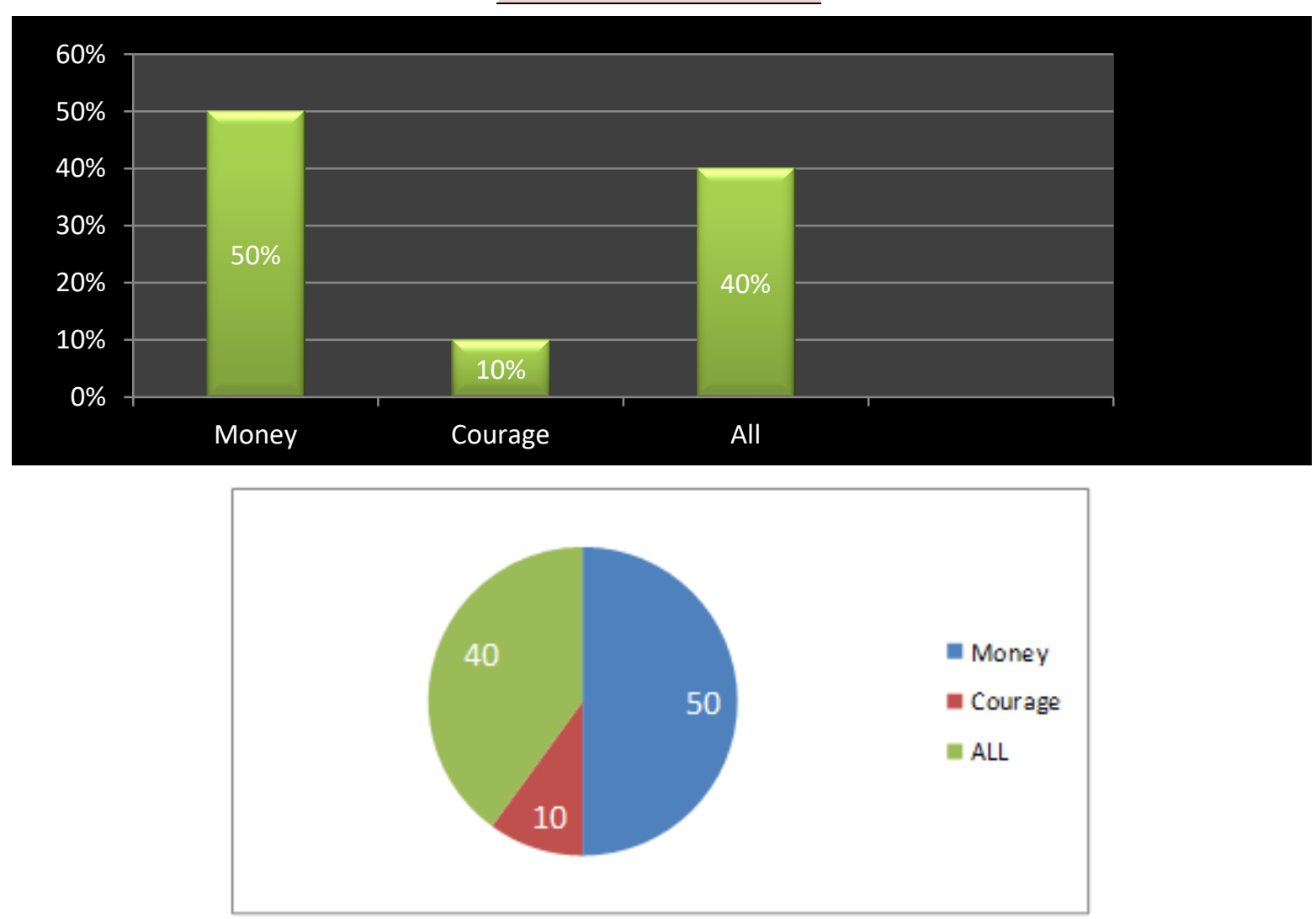


\subsection{FINDINGS \& ANALYSIS}

- Job market is more complicated than entrepreneurship.

- In terms of socio-economic development, it has a great role to play.

- There prevails lack of training facilities regarding entrepreneurship.

- Entrepreneurship is very easy to start a new business if we have enough money \& courage.

- If we are an entrepreneur, we become an independent person, create employment and contribute to GDP growth.

- Majority believes entrepreneurship is a risky venture as all the risks are to be borne by the owner.

- If Govt. will manage sufficient training and loan arrangement, then we can say that entrepreneurship can be an alternative to job market.

- Lack of money is the major demotivating factor to facilitate entrepreneurship in Bangladesh.

\subsection{RECOMMENDATIONS}

- Make the formation of entrepreneurial activity a government priority - the formulation of effective policy for entrepreneurial ecosystems requires the active involvement of Government

- The outlook of the society needs to be corrected.

- Rules and regulations need to be simple and easy to understand in terms of owning a new business.

- More practical and broad studies associated with entrepreneurship needs to be included in the education system.

- Arrangement of proper training facilities throughout the country.

- Awareness among mass people can be created so that people get motivated.

- Make loans available on easy terms.

\subsection{CONCLUSION}

By analyzing everything, it can be said that the job market of our country is not good at all. So entrepreneurship is an important tool to solve this problem. Our government \& non-government authorities cannot provide sufficient job opportunities for the youths. Because these opportunities are limited. If government \& nongovernment authorities can take appropriate steps like capital funding, political stability, keep the inflation \& deflation rate in reasonable level $\&$ also providing subsidies. It may be the major source of alternative job market. Basically people want to enter into the entrepreneurship because it has freedom \& a great chance of earning huge amount of money. But they cannot do this. So it can be cleared that an entrepreneur is a appropriate alternative of job market for the unemployed youth.

\section{References}

- Jonathan T. Eckhardt, Scott A. Shane (2003). Opportunities and Entrepreneurship. Journal of Management,

- Md. Shabbir Nowsher and co-authored by Omar Farhan Khan (2019). "LightCastle Featured Insights 2019".

- Seyed Morteza Afghah, Ali Raoof and Simin Hoshyar (2014). A study on the effect of entrepreneurship on economic growth.

- Giuseppina Maria Cardella, Brizeida Raquel Hernández-Sánchez and José Carlos Sánchez García (2020). Entrepreneurship and Family Role: A Systematic Review of a Growing Research.

- Uddin, Shamsu (2016), "The Impact of Aid on Economic Growth of Bangladesh: A Review",Thoughts on Economics, Vol. 25, Issue 3 \& 4 | December 2016.

- Bosma, N.S., Wennekers, S., Amoros, J. E. (2012), "Global Entrepreneurship Monitor 2011: Extended Report: entrepreneurs and Entrepreneurial employees Across the Globe", Boson College,Babson Park, MA, U S, Universidad Del Desarrollo, Santiago, Chile, Universiti Tun Ablolrazzak, Malaysia, London Business School, London, U K

- Audretsch, D, B. (2007), "The Entrepreneurial Society", Oxford: Oxford University Press

- Ahmed, I., Nawaz, M. M., and Ramzan, M. (2012). Do external factors influence students' entrepreneurial inclination? An evidence based approach. Actual Prob. Econ. 125, 51-58. doi: 10.5772/36570

- Aldrich, H. E., and Cliff, J. E. (2003). The pervasive effects of family on entrepreneurship: toward a family embeddedness perspective. J. Bus. Ventur. 18, 573-596. doi: 10.1016/S0883-9026(03)00011-9

- Audretsch, D. B., Belitski, M., and Desai, S. (2015). Entrepreneurship and economic development in cities. Ann. Reg. Sci. 55, 33-60. doi: 10.1007/s00168-015-0685-x

- Bignotti, A., and le Roux, I. (2016). Unravelling the conundrum of entrepreneurial intentions, entrepreneurship education, and entrepreneurial characteristics. Acta Commercii 16, 1-10. doi: 10.4102/ac.v16i1.352

- Cabeza-Ramírez, L. J., Sanchez-Cañizares, S. M., and Fuentes-García, F. J. (2017). Entrepreneurship as a 
dynamic field of study: a bibliometric analysis of research output. Tourism Manag. Stud. 13, 59-71. doi: 10.18089/tms.2017.13307

- Zellweger, T., Sieger, P., and Halter, F. (2011). Should I stay or should I go? Career choice intentions of students with family business background. J. Bus. Ventur. 26, 521-536. doi: 10.1016/j.jbusvent.2010.04.001

- Shane, S. (2000). Prior knowledge and the discovery of entrepreneurial opportunities. Org. Sci. 11, 448-469. doi: 10.1287 /orsc. 11.4 .448 .14602 